\title{
Preliminary study of mechanic workshop soil amended with juice extracted from Lime (Citrus aurantifolia)
}

\author{
Stephen, E. ${ }^{{ }^{\star}}$, Otorkpa, O. J. ${ }^{2}$, Adejo, P. O. ${ }^{1}$ and Shaibu, L. ${ }^{1}$ \\ 1Department of Microbiology, Kogi State University, P.M.B. 1008, Anyigba-Kogi State, Nigeria. \\ ${ }^{2}$ Texila American University, Georgetown, Guyana, USA. \\ *Corresponding Author. Email: Stephen.e@ksu.edu.ng. Tel: +234-8036347036.
}

Copyright (c) 2016 Stephen et al. This article remains permanently open access under the terms of the Creative Commons Attribution License 4.0, which permits unrestricted use, distribution, and reproduction in any medium, provided the original work is properly cited.

Received 12th September, 2016; Accepted 5th October, 2016

\begin{abstract}
Bioremediation potential of lime extract (Citrus aurantifolia) on mechanic workshop soil was studied for a period of 56 days. The microbial enumeration was carried out using serial dilution and pour plate method. The bacteria count ranged from $6.3 \times 10^{3}$ to $6.8 \times 10^{4} \mathrm{cfu} / \mathrm{g}$ for oil free soil (OFS), $0.8 \times 10^{3}$ to $9.8 \times 10^{4} \mathrm{cfu} / \mathrm{g}$ for mechanic workshop soil (MS) and $1.24 \times 10^{4}$ to $4.16 \times 10^{4} \mathrm{cfu} / \mathrm{g}$ for mechanic workshop soil amended with lime extract (MSAL). The fungal count ranged from $2.1 \times 10^{3}$ to $2.7 \times 10^{3} \mathrm{cfu} / \mathrm{g}$ for amended soil, $2.5 \times 10^{3}$ to $3.0 \times 10^{4} \mathrm{cfu} / \mathrm{g}$ for unpolluted and $2.2 \times 10^{3}$ to $4.0 \times 10^{4}$ $\mathrm{cfu} / \mathrm{g}$ for polluted soil. There were significant differences in both bacteria and fungi count at $5 \%$ probability level. Micrococcus sp, Staphylococcus sp, Pseudomonas sp, Bacillus sp, Proteus sp Mucor sp, Microsporum sp, Aspergillus niger, Aspergillus flavus, Saccharomyces $\mathrm{sp}$, Rhizopus $\mathrm{sp}$ and Aspergillus fumigatus were isolated in this study. MSAL had higher moisture content, phosphorus, organic matter, organic carbon and nitrate compared to OFS and MS. There were significant differences $(\mathrm{p}<0.05)$ in the $\mathrm{pH}$, phosphorus, organic matter, organic carbon between OFS, MS and MSAL. This study revealed that lime (Citrus aurantifolia) extract has a potential for remediating mechanic workshop soil.
\end{abstract}

Keywords: Bioremediation, Citrus aurantifolia, lime extract, organic carbon.

\section{INTRODUCTION}

Contamination of soils with oil in the environment has been reported by Yakubu (2007) as a well recognised problem in today's world. Oil spills affect many species of plants and animals in the environment as well as humans. Contamination of soils with petroleum hydrocarbons is a growing concern in many countries (Agamuthu et al., 2010). The indiscriminate disposal of spent lubricating oil by motor mechanics is a common source of spent lubricating oil contamination of soil in countries like Nigeria that do not enforce strict compliance to environmental laws (Ogbo et al., 2009).

Spent engine oil is a common and toxic environmental contaminants not naturally found in the environment (Dominguez-Rosado and Pichtel, 2004). large amount of spent oil are liberated into the environment when motor oil is changed and disposed into the soil by motor mechanics and generator artisans including small scale lubricating oil merchants along the road (Odjegba and Sadiq, 2002; Achuba and Clarke- Peretiemo, 2008).
Oil is released into the environment from exhaust system during engine use and also due to engine leaks (Osubor and Anoliefo, 2003). According to Ogbo et al. (2009), oil contamination causes low rate of germination in plants. Adam and Duncan (2002) also reported that this effect could be due to the oil which acts as a physical barrier preventing or reducing access of the seeds to water and oxygen. Oil released into the environment affects many plants, animals, microorganisms and humans within the oil impacted environment. Additionally, prolonged exposure to oil as well as high concentration of oil could cause the development of liver or kidney disease, possible damage to the bone marrow and an increased risk of cancer (Mishra et al., 2001).

Petroleum products such as engine oil, petrol and diesel are used daily in various forms in mechanic workshops. These products tends to harden and change the colour of the soil, which may have untold hazards to automobile technicians (Udeani et al., 2009). Abandoned 
mechanic workshop soil cannot be used for agricultural purposes because of the different hydrocarbon products used and discarded over a long time. Hence there is the need to reclaim such polluted soil.

Application of lime to contaminated soils has been reported to significantly improve soil fertility (Yamoah et al., 1996). The effect of lime is long lasting but not permanent (Fageria et al., 2008). Lime is readily available and it is not expensive. The application of lime significantly increased soil $\mathrm{pH}$, available phosphorus and the amount of soil exchangeable aluminium (Ruganzu, 2009).

Lime is an acidic substance that raises the $\mathrm{pH}$ of the soil. When Lime is added to soil it increases the $\mathrm{pH}$ of the soil.

Lime tree (Citrus aurantifolia) is widely grown in tropical and subtropical areas. Limes exceed lemons in both acid and sugar content (Morton, 1987).

Different methods have been employed in remediating contaminated soil with each having one form of disadvantage or the other. Bioremediation makes use of indigenous oil-consuming microorganisms. According to Gentry et al. (2004), these indigenous organisms can naturally degrade large hydrocarbons and utilise them as source of food. Microbial remediation of hydrocarbon contaminated sites is accomplished with the help of a diverse group of microorganisms, particularly indigenous bacteria present in soil. These microorganisms can degrade a wide range of target constituents present in oily sludge (Barathi and Vasudevan, 2001; Mishra et al., 2001).

The significance of this preliminary study however, lies in the use of extract from Citrus aurantifolia which contains natural sugar and is completely biodegradable to amend mechanic workshop polluted soil.

\section{MATERIALS AND METHODS}

\section{Sample Collection}

Oil polluted soil sample was collected from a mechanic workshop opposite Kogi State University (KSU) first gate, Ankpa road, Anyigba. Anyigba lies between latitudes $7^{0}$ $29^{1}$ North and longitude $7^{0} 11^{1}$ East and falls within the rain forest belt of Nigeria (Stephen and Egene, 2012).

The samples were collected at a depth of 0 to $5 \mathrm{~cm}$ from three different points into two perforated plastic pots labelled A and B, while soil sample devoid of oil was collected from soil around the Faculty of Natural Sciences of Kogi State University Anyigba, into the third pot (C) which served as the control for this study. All the pots contained $6.0 \mathrm{~kg}$ of soil each.

\section{Procedure}

In the $6.0 \mathrm{~kg}$ of soil (mechanic workshop soil) in A, 1000 $\mathrm{ml}$ (1 litre) of lime extract used as amendment was incorporated into the soil to achieve $16.7 \%$ amendment level. Pot B contained only mechanic workshop soil while C contained pristine soil (control). The three soil samples were kept in Microbiology laboratory Kogi State University, and were watered twice with 500 millilitres a week for a period of eight (8) weeks. Sampling was conducted bi-weekly for period of 56 days (8 weeks) to determine the microbiological components and physicochemical properties of the soil. The soil samples from the three pots were analyzed microbiologically as described by Public Health England (2014). The pH was determined as described by Thomas (1996). Nitrate was determined by the micro Kjedahl method (Association of Official Analytical Chemist, AOAC, 2005). The phosphorus content and moisture were determined as described by Kellog Soil Survey laboratory Methods Manual (1996) method.

\section{Sample Analysis}

Descriptive statistics and analysis of variance (ANOVA) was performed using procedure of SPSS version 16 (2007). Experimental precision achieved was reported at $5 \%$ probability level.

\section{RESULTS AND DISCUSSION}

Figure 1 shows the total bacteria counts obtained from oil free soil (OFS), mechanic workshop soil (MS), and mechanic workshop soil amended with lime extract (MSAL). Higher bacteria counts were observed in MSAL than in OFS and MS. The bacteria count ranged from $6.3 \times 10^{3}$ to $6.8 \times 10^{4} \mathrm{cfu} / \mathrm{g}$ for OFS, $8.0 \times 10^{3}$ to $9.8 \times 10^{4} \mathrm{cfu} / \mathrm{g}$ for MS and $1.24 \times 10^{4}$ to $4.16 \times 10^{5} \mathrm{cfu} / \mathrm{g}$ for MSAL. The highest bacteria count was recorded in MSAL at day 14 . There were significant differences in the bacteria count between the treatments at $5 \%$ probability level. The organisms identified were Micrococcus species, Staphylococcus species, Pseudomonas species, Bacillus species, Proteus species and Escherichia coli. Microbiological analysis revealed higher bacteria count in mechanic workshop soil amended with lime extract (MSAL) compared to mechanic workshop soil (MS) and oil free soil (OFS). This may be due to the amendment with lime extract (MSAL) which improved the nutrient content of the soil allowing more organisms to flourish. This is in agreement with the findings of Chorom et al. (2010). These authors observed high bacteria count in crude oil polluted soil amended with lime fertilizer.

Figure 2 shows the fungi count from oil free soil (OFS), mechanic workshop soil (MS) and mechanic workshop soil amended with lime extract (MSAL). The fungi counts ranged from $2.5 \times 10^{3}$ to $3.0 \times 10^{4} \mathrm{cfu} / \mathrm{g}$ for OFS, $2.2 \times 10^{3}$ to $4.0 \times 10^{4} \mathrm{cfu} / \mathrm{g}$ for MS and $2.1 \times 10^{3}$ to $2.7 \times 10^{3} \mathrm{cfu} / \mathrm{g}$ for 


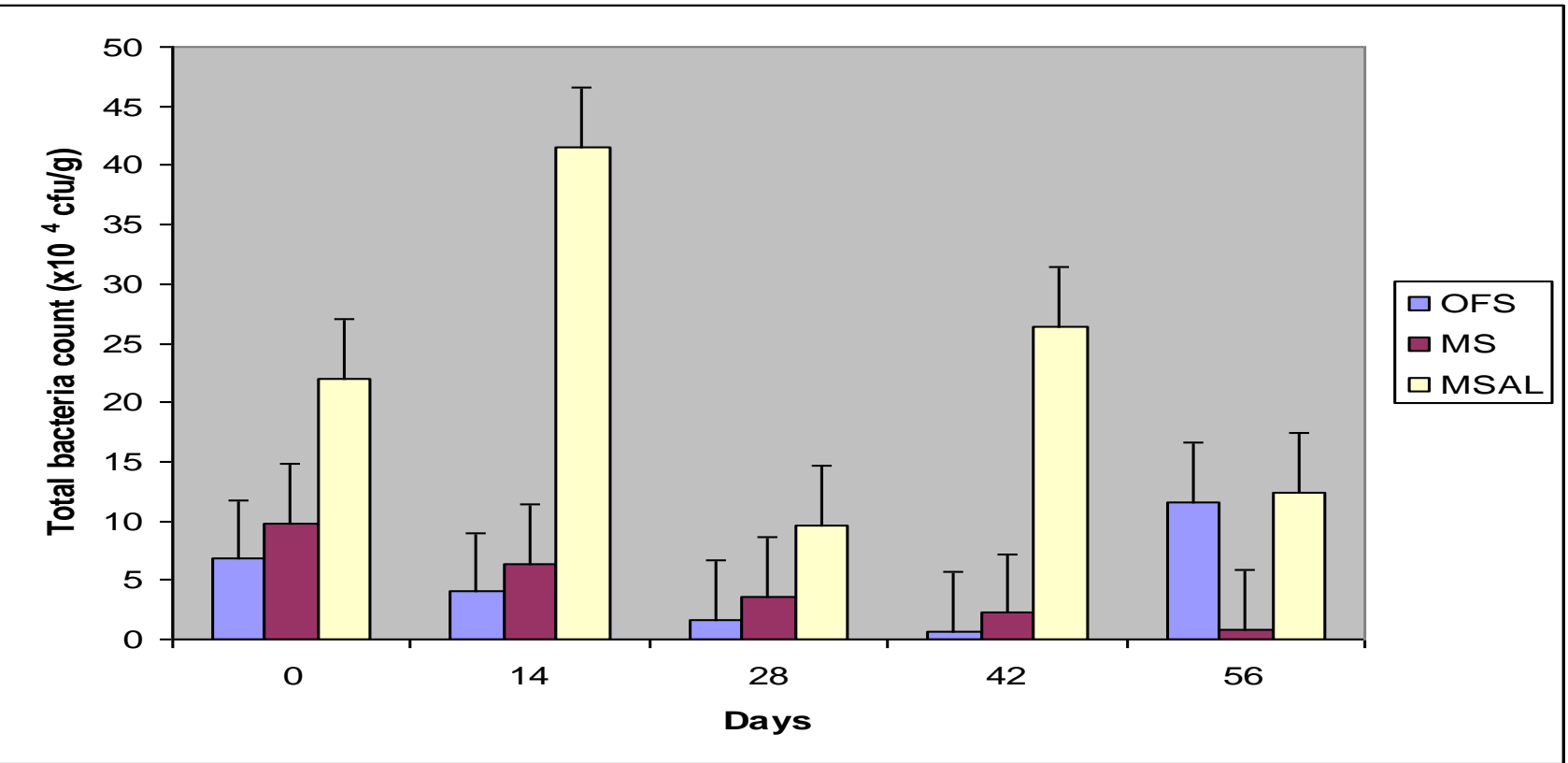

Figure 1. Total viable counts obtained from mechanic workshop soil undergoing Bioremediation. OFS, Unpolluted soil, MS, Mechanic workshop soil, MSAL, Mechanic workshop soil Amended with lime extract.

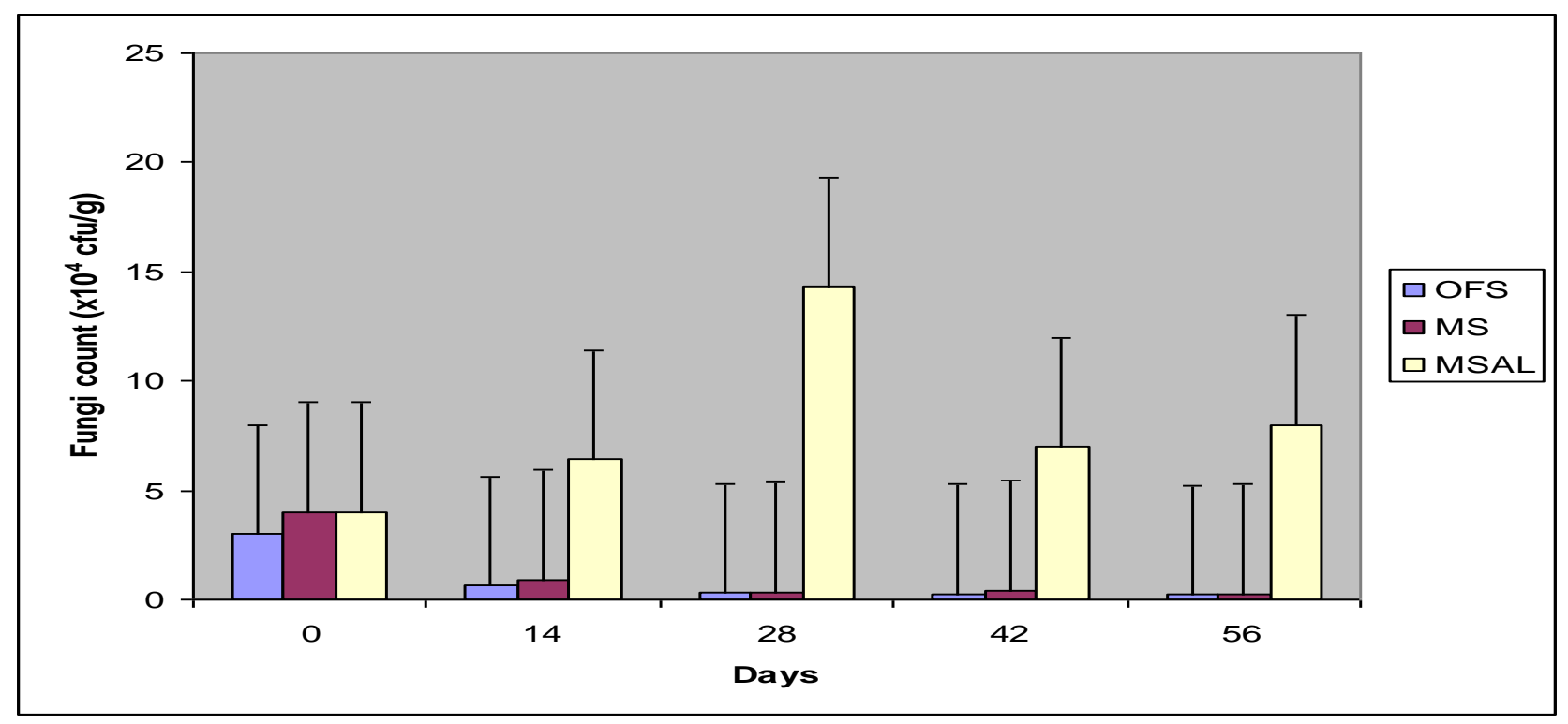

Figure 2. Total viable fungi counts obtained from mechanic workshop soil undergoing bioremediation. OFS, Unpolluted soil, MS, Mechanic workshop soil, MSAL, Mechanic workshop soil Amended with lime extract.

MSAL. The highest fungi count was observed in MSAL at day 28 while the lowest fungi count was observed in OFS at day 56. The fungi isolated were Aspergillus niger, A.flavus, A. fumigatus, Sacchromyces sp, Rhizopus sp, Microsporum sp and Mucor sp. The fungi count was also higher in mechanic workshop soil amended with lime extract (MSAL) than the unamended mechanic soil (MS) and the oil free soil (OFS). This result is in agreement with earlier works by Stephen et al. (2013a,b). These authors observed higher fungi counts in soils amended with plant remains.

The frequency and occurrence of bacteria and fungi isolated from OFS, MS and MSAL is shown in Table 1. Mucor sp had the highest frequency of occurrence with 
Table 1. Frequency and Occurrence of Isolates obtained from mechanic workshop soil undergoing bioremediation.

\begin{tabular}{lccccc}
\hline Organisms & OFS & MS & MSAL & Total & \% Total \\
\hline Aspergillus flavus & 1 & - & 1 & 2 & 3.45 \\
Aspergillus fumigatus & - & 2 & 2 & 4 & 6.90 \\
Aspergillus niger & 2 & 1 & 2 & 5 & 8.62 \\
Bacillus sp & 5 & 4 & 2 & 11 & 18.97 \\
Micrococcus sp & 1 & 1 & 3 & 5 & 8.62 \\
Mucor $s p$ & 5 & 4 & 4 & 13 & 22.41 \\
Pseudomonas sp & 1 & 2 & 3 & 6 & 10.34 \\
Proteus sp & - & 3 & 1 & 4 & 6.90 \\
Rhizopus sp & 1 & 2 & 1 & 4 & 6.90 \\
Saccharomyces sp & - & 1 & - & 1 & 1.72 \\
Staphylococcus $s p$ & 1 & 1 & 1 & 3 & 5.17 \\
Total & 17 & 21 & 20 & 58 & 100 \\
\hline
\end{tabular}

OFS, Unpolluted soil, MS, Mechanic workshop soil, MSAL, Mechanic workshop soil Amended wilt lime extract.

$22.41 \%$ followed by Bacillus $\mathrm{sp}$ with $18.97 \%$, Pseudomonas sp 10.34\%, Staphylococcus sp and Aspergillus niger had $8.62 \%$, Proteus spp, Rhizopus spp and Aspergillus fumigatus $6.90 \%$, Micrococcus spp had $5.17 \%$, Aspergillus flavus $3.45 \%$ while Saccharomyces spp had the least frequency with $1.72 \%$. Similar result was obtained in an earlier study by Stephen et al. (2016). However, in addition to the above organisms, the authors reported the occurrence of Candida tropicalis (1.72\%) in mechanic workshop soil undergoing bioremediation amended with lime fertilizer. In this study, the total microbial load was more in the unamended mechanic workshop soil (MS) followed by the amended soil (MSAL) and OFS. This may be due to the remediation process going on and probably with time, the amended soil (MSAL) may have more microbial load than OFS and MS.

The physicochemical qualities of the lime extract (juice) revealed an acidic $\mathrm{pH}$ of 2.64, nitrate concentration of $0.80 \%$ and phosphorus content of $21.30 \%$. Lime extract is acidic, poor in nitrogen but contains high phosphorus content. This finding is in agreement with Ruganzu (2009) who reported that lime contains high amount of phosphorus which may increase microbial activity in the soil.

The physicochemical parameters of the soil samples analyzed were shown in Table 2 . The $\mathrm{pH}$ ranged from $5.54 \pm 0.23$ to $6.46 \pm 0.29$. The highest $\mathrm{pH}$ was observed in oil free soil while the least $\mathrm{pH}$ was observed in MSAL. There were significant differences $(p<0.05)$ in the $\mathrm{pH}$ between OFS, MS and MSAL. The $\mathrm{pH}$ in the amended soil was lower than unamended mechanic workshop soil and oil free soil. This may be due to the acidic juice (2.64) incorporated into the soil. This result is in sharp contrast to the result of Stephen et al. (2013a) who observed a higher $\mathrm{pH}$ in mechanic workshop soil amended with cow pea chaff.

The highest moisture content was observed in MSAL followed by MS and OFS. It ranged from $7.01 \pm 3.08$ to $10.46 \pm 1.80 \%$. There was no significant difference $(p>0.05)$ in the moisture content between the treatments. The moisture contents of the samples were high. This may be due to the consistent watering of the soil. This is in agreement with Stephen and Egene (2012). They observed high moisture content in spent lubricating oil polluted soil receiving constant water.

Phosphorus content was high in all treatment. However, it was higher in MSAL compared to MS and OFS. The phosphorus content ranged from $8.06 \pm 0.94$ to $11.26 \pm 0.92 \%$. There were significant differences between the treatments at $5 \%$ probability level. The phosphorus content was higher in the MSAL and MS .This agrees with the findings of Ijah and Abioye (2003) who reported increase in phosphorus contents in soil polluted with hydrocarbon products. Moreover, the lime extract had high phosphorus content which may also be responsible for the higher phosphorus result obtained in MSAL.

Nitrate content was low in both OFS and MS compared to MSAL. It ranged from $0.09 \pm 0.02$ to $2.73 \pm 2.09 \%$. The highest nitrate content was observed in MSAL followed by MS. There was no significant difference in the nitrate concentration at $5 \%$ probability level. The nitrate content was higher in MSAL compared to MS and OFS. This may be due to increase rate of organic matter decomposition as a result of the amendment (Stephen et al., 2016). A similar result was reported by Atagana (2008) who worked on compost manure.

There was a linear increase in the organic matter content of the soil samples from OFS to MSAL. The least organic matter content was observed in OFS while the highest value was recorded in MSAL. There was a 
Table 2. Physicochemical qualities of mechanic workshop polluted soil undergoing bioremediation $(\mathrm{M}+\mathrm{SE})$

\begin{tabular}{lccc}
\hline Parameter & OFS & MS & MSAL \\
\hline $\mathrm{pH}$ & $6.46 \pm 0.29^{\mathrm{a}}$ & $6.22 \pm 0.22^{\mathrm{a}, \mathrm{b}}$ & $5.54 \pm 0.23^{\mathrm{a}}$ \\
Moisture (\%) & $7.01 \pm 3.08^{\mathrm{a}}$ & $8.12 \pm 1.66^{\mathrm{a}}$ & $10.46 \pm 1.80^{\mathrm{a}}$ \\
Nitrogen (\%) & $0.09 \pm 0.02^{\mathrm{a}}$ & $0.19 \pm 0.03^{\mathrm{a}}$ & $2.79 \pm 2.09^{\mathrm{a}}$ \\
Phosphorus (\%) & $8.06 \pm 0.94^{\mathrm{a}}$ & $10.40 \pm 1.00^{\mathrm{a}, \mathrm{b}}$ & $11.26 \pm 0.92^{\mathrm{a}}$ \\
Organic carbon (\%) & $0.60 \pm 0.04^{\mathrm{b}}$ & $1.04 \pm 0.05^{\mathrm{b}}$ & $3.27 \pm 0.42^{\mathrm{a}}$ \\
Organic matter (\%) & $1.04 \pm 0.04^{\mathrm{b}}$ & $1.60 \pm 0.26^{\mathrm{b}}$ & $4.0 \pm 0.86^{\mathrm{a}}$ \\
$\mathrm{EC}(\mathrm{Ms} / \mathrm{cm})$ & $0.50 \pm 0.11^{\mathrm{a}}$ & $0.49 \pm 0.07^{\mathrm{a}}$ & $0.91 \pm 0.51^{\mathrm{a}}$ \\
\hline
\end{tabular}

a,b,c, means denoted by different superscripts along the same row are significantly $(p<0.05)$ different. Values are mean of five replicates. OFS, Unpolluted soil, MS, Mechanic workshop soil, MSAL, Mechanic workshop soil Amended wilt lime extract, EC, Electrical conductivity.

significant difference $(p<0.05)$ in the organic matter content between the treatments. Similar trend in organic matter content was observed in the organic carbon. The highest value of organic carbon was recorded in MSAL while the least value was observed in OFS. There was a significant difference $(p<0.05)$ in the organic carbon between OFS, MS and MSAL. The organic matter and organic carbon contents were higher in MSAL compared to MS and OFS. This may be due to accumulation of organic compounds in oil polluted soil (Ayotamuno et al., 2006). According to Tester (1990) and Darby et al. (2006), repeated applications of organic materials and compost can increase the level of soil organic matter which can also enhance microbial activity (Darby et al., 2006).

The electrical conductivity (EC) was low in all soil samples regardless of treatment. The EC ranged from $0.50 \pm 0.11 \mathrm{Ms} / \mathrm{cm}$ to $0.91 \pm 0.51 \mathrm{Ms} / \mathrm{cm}$. there was no significant difference in the electrical conductivity at $5 \%$ probability level between the treatments. The higher electrical conductivity observed in MSAL compared to MS and OFS may be due to the bioremediation process resulting in the release of salts and ions from the oil polluted soil (Stephen et al., 2013a). The values of electrical conductivity in this study were higher than earlier works by Stephen et al. (2013a). The reason may be due to the high biodegradable liquid nature of the lime extract used in this study compared to cowpea chaff.

\section{Conclusion}

The results of this preliminary study showed that the use of lime extract can improve the microbial activity and physicochemical properties of hydrocarbon polluted soil time. Phosphorus, organic matter content and organic carbon were higher in the amended soil compared to the unamended soil and the free soil suggesting that lime extract has a potential for remediating mechanic workshop polluted soil as it contain natural sugar which probably enhanced biodegradation of hydrocarbon polluted mechanic workshop soil.

\section{CONFLICT OF INTEREST}

The authors declare that they have no conflict of interest.

\section{REFERENCES}

Achuba, I, \& Clerk-Peretiemo, B. O. (2008). Effect of spent engine oil on soil catalase and dehydrogenase activities, Int. Agrophysics, 22, 1-4.

Adam, G. I., \& Duncan, H. (2002). Influence of diesel on seed germination. Env.pollut. 120: 363-370.

Agamuthu P, Abioye OP \& Abdul Aziz A. 2010. Phytoremediation of soil contaminated with used lubricating oil useing Jatropha curcas. J. Hazardous Materials, 179,891894.

AOAC International. (2005). Official method of analysis of AOAC International. Chemistry and analytical-laboratory manual $\left(18^{\text {th }}\right.$ ed.).

Atagana, H. I. (2008). Compost bioremediation of hydrocarbon contaminated soil inoculated with organic manure. Afri. J. Biotech., 7(10), 1516-1525.

Ayotamuno, M. J, Kogbara, R. B., \& Egwuenum, P. N. 2006. Comparison of corn and Elephant grass in the phytoremediation of petroleum hydrocarbon Contaminated Agriculture soil in PortHarcourt, Nigeria. J. of Agric and Env., 4(24), 218-222.

Barathi, S., \& Vasudevan, N. 2001. Utilisation of petroleum hydrocarbon by pseudomonas fluorescent isolated from a petroleum-contaminated soil. Env. Intern., 26(5-6), 413-416.

Chorom, M., Sharifi, H. S., \& Motamedi, H. (2010). Bioremediation of a crude oil-polluted soil by application of fertilizers. Iranian J. of Env. Health Sci. Eng., 7(4), 319-326.

Darby, H. M., Stone, A. G., \& Dick, R. P. (2006). Compost and manure mediated impacts on soil-borne pathogens and soil quality. Soil Sci. Soc. America J., 70(2), 347-358.

Dominguez-Rasado, E., \& Pichtel, J. (2004). Phytoremediation of soil contaminated with used motor oil. J. Env. Eng. Sci., 
21(2), 169-173.

Fageria, N. K., \& Baligar, V. C. (2008). Ameliorating soil acidity of tropical oxisols by liming for sustainable crop production. In: Advances in Agronomy, Sparks, D. L., Ed., Pp. 345-389.

Gentry, T. J., Rensing, C., \& Pepper, I. L. (2004). New approaches for bioaugumentation as remediation technology. Crit. Rev. Environ. Sci. Teachn., 34(5), 447-494.

ljah, U. J. J., \& Abioye, O. P. (2003). Assessment of Physiochemical and Microbiological properties of soil 30 months after kerosene spill. J. Res. Sci. Management, 1(1), 24-30.

Kellog Soil Survey Laboratory Manual. (1996). Soil Survey Laboratory Methods Manual. Soil survey investigations report no. 42. Ver. 3.0. USDA-NRCS, Lincoln, NE.

Mishra, S., Jyot, J., Kuhadi, R. C., \& Lai, B. (2001). Evaluation of inoculum addition to stimulate in situ of inoculum addition to stimulate in situ Bioremediation of oily-sludge contaminated soil. Appl. Env. Micro. 69(4), 295- 306.

Morton, J. F. (1987). Fruits of warm climates. Creative Resource Systems, Inc, Miami. Pp. 134-142.

Ogbo, E. M., Avwerosovwe, U, \& Odogu, G. (2009). Screening of four common weeds for use in phytoremediation of soil contaminated with spent lubricating oil. Afri.J. Plant Sci., 3(5), 102-106.

Osubor, C. C., \& Anoliefo, G. O. 2003. Inhibitory effect of spent lubricating oil on the Arachis hypogea L. Benin Sci. Dig. 1, 73-79.

Public Health England. (2014). Preparation of samples and dilutions, plating and sub-culture. Microbiology Services. Food, Water and Environmental Microbiology Standard Method FNES26 (F2); Version 1, PHE Microbiology Services, Food, Water and Environmental Microbiology working group

Ruganzu, V. (2009). Potential of improvement of Acid soils fertility by incorporation of natural fresh plant Biomass combined with travertine in Rwanda. PhD thesis submitted to Agricultural University, Gembloux, Belgium.
Stephen, E., \& Egene, U. M. (2012). Microbiology and physicochemical properties of soil polluted with lubricating oil in Anyigba, Kogi State, Nigeria. Nig J. Tech. Res., 7(2), 4952.

Stephen, E., Job, O. S., \& Abioye, O. P. (2013a). Study on Biodegradation of Diesel contaminated soil amended with cowpea chaff. J. Sci. Multi. Res., 2(1), 14-18.

Stephen, E., Usman, A. S., Okolo, M. O., Akogu, E. A., \& Abioye, O. P. (2013b). Microbiology and physicochemical properties of diesel polluted soil. Futa J. Res. Sci., 9 (1), 8286.

Stephen, E., Okwute, L. O., Idoko, P. A., \& Makolo, D. (2016). Study on Biodegradation of Mechanic Workshop Polluted Soil Amended with Lime Fertilizer. Int. J. Env. Moni. Anal., 4(1) 21-26. doi: 10.11648/j.jiema.20160401.14

Tester, C. F. (1990). Organic amendment effects on physical and chemical properties of a sandy soil. Amer. J. Soil Sci Soc., 54: 827-831.

Thomas, G. W. (1996). Soil pH and soil acidity. InNelson, D. W., Sommers, L. E., Sparks, D. L., \& Page, A. L. (eds.) Methods of soil analysis. Part 3. Chemical methods. SSSA, Madison, WI. Pp. 475-490.

Udeani, T. K. C., Oboroh, A. A., Okwuosa, C. N., Achukwu, P. V., \& Azubike, N. (2009). Isolation of bacteria from mechanic workshops soil environment contaminated with used engine oil; Afri. J. Biotech., 8 (22), 6301-6303.

Yakubu, M. B. (2007). Biodegradation of Lagoma crude oil using pig dung. Afri. J. of Biotech., 6(24), 2821-2825.

Yamoah, C., Ngueguim, M., Ngong, C., \& Dias, D. K. W. (1996). Reduction of $\mathrm{P}$ fertilizer requirement using lime and mucuna on high P-sorption soils of NW Cameroon, Afri. Crop Sci. J. 11, 441-457. 